\title{
The prevalence of "high-risk" HPV types in penile condyloma-like lesions: correlation between HPV type and morphology
}

\author{
G-B Löwhagen, A Bolmstedt, W Ryd, E Voog
}

\begin{abstract}
Objective-To evaluate the prevalence of "high-risk" human papilloma virus (HPV) types in penile condyloma-like lesions and to correlate HPV types with clinical and histological features.

Design-The study included 94 male patients with signs of penile HPV infection. From acuminate, papular and macular lesions, specimens were collected for HPV DNA hybridisation, using the dot blot and Southern blot techniques. Biopsy specimens from 51 cases were examined by light microscopy for signs of koilocyto-
\end{abstract} sis and dysplasia.

Setting-The STD outpatient clinic of the Department of Dermatovenereology of Sahlgrenska Hospital, Göteborg, Sweden.

Results-In 79 (90\%) of 88 patients HPV DNA was detected by dot blot. Of 51 cases examined by histology $88 \%$ disclosed an evident koilocytosis. "High-risk" HPV types $(16,18,31,33,35)$ were demonstrated in $8 \%$ of acuminate, $24 \%$ of papular and $56 \%$ of macular lesions. In $29 \%$ of 51 lesions examined histologically moderate to severe dysplasia was observed. There was a significant correlation between "high-risk" HPV types and dysplasia.

Conclusion-"High-risk" HPV types are prevalent in papular and especially macular penile condyloma-like lesions. The histological finding of koilocytosis concomitant with dysplasia strongly indicates infection with a "high-risk" HPV type. Although the risk of penile cancer is low, it is from an epidemiological point of view important to diagnose these lesions. Until simple tests for HPV typing are available, biopsy for light microscopy (histology) should be obtained liberally from papular and macular condyloma-like lesions. In atypical cases of balanoposthitis HPV aetiology should also be considered.

(Genitourin Med 1993;69:87-90)

\section{Introduction}

Human papilloma virus (HPV) infection is today the most prevalent sexually transmitted disease (STD) in western countries. Besides the classical genital HPV lesion, condyloma acuminata, HPV gives a spectrum of clinical lesions in the ano-genital region. There is a need for reliable methods of diagnosing these lesions. Different DNA hybridisation methods of identifying the virus are now becoming available. The value and the sensitivity of these HPV tests in routine diagnostic work has not yet been fully evaluated. About 20 genotypes of HPV with trophism for the genital mucosa have been characterised. Much attention has been focused on the association between specific "high-risk" HPV types $(16,18,31,33$, 35) and intraepithelial neoplasia, especially cervical cancer. ${ }^{1}$ Acuminate lesions are mostly associated with HPV types 6 and $11 .^{2}$ A specific clinical entity caused by "high-risk" HPV types has been described as Bowenoid papulosis. ${ }^{34}$ Although the risk of cancer in penile HPV lesions is very low it might from an epidemiological point of view be of importance to identify lesions caused by "high-risk" HPV types also in men.

The aim of this study was to evaluate the prevalence of "high-risk" HPV types in penile condyloma-like lesions and to correlate HPV types with clinical and histological features.

\section{Patients and methods}

The study comprised 94 consecutive male patients with signs of penile HPV infection seen by the authors (GBL, EV) at the STD Clinic Sahlgrenska Hospital, Göteborg between August 1989 and January 1991. The mean age of the patients was 28 years (range 17 to 59). Patients who had been treated during the last month for condylomata were not included.

Besides careful inspection, the skin/mucosa of the penis was covered with gauze soaked in 5\% acetic acid for 3-5 minutes and thereafter examined with a magnification lamp. The lesions were categorised as acuminate, papular or macular. Acuminate lesions were pedunculated exophytically growing tumours with finger-like or rounded papillary projections. Papular lesions were sessile with smooth or rough surface but no real filiform projections. Macular lesions could be identified after acetic acid treatment as white, well-circumscribed, flat lesions, either as small spots or confluent plaques, sometimes with punctuation seen as small red spots corresponding to capillaries. This division is arbitrary and transitional forms were sometimes observed. The three different types could be seen in the same patient. Biopsy specimens were taken from the type of lesion that dominated the clinical picture. In seven patients with only macular lesions the symptomatology was as for balanitis.

Biopsy specimens $(2-4 \mathrm{~mm})$ were taken by 
punch or scissors for histology and HPV typing from the same lesion. Local anaesthesia was induced either by infiltrating $0.5 \%$ lidocaine or by applying a cream (Emla, Astra, Sweden) containing $2.5 \%$ lidocaine and $2.5 \%$ prolocaine with occlusion for 5-10 minutes. In patients who refused biopsy, epithelial cells were collected for HPV typing using a cytology brush (Cytobrush, Medscand AB, Malmö).

\section{Virology}

Sample preparation: Material was collected into tubes containing $1 \mathrm{ml}$ of lytic buffer (Oncor Inc. Gaithensburg, MD, USA) and digested with proteinase $\mathrm{K}$, final concentration $0.5 \mathrm{mg} / \mathrm{ml}$, in the same buffer at $60 \mathrm{C}$. Cells collected by cytobrush were digested for $1 \mathrm{~h}$ until the specimen was no longer visible. Thereafter the digested samples were divided into two aliquots, $250 \mu$ for dot-blot hybridisation and $750 \mu \mathrm{l}$ for Southern blot hybridisation.

Dot-blot hybridisation: The $250 \mu \mathrm{l}$ aliquots were subjected to two separate dot-blot hybridisation assays performed in parallel. One assay monitored that the samples contained sufficient amounts of DNA by hybridisation with a biotinylated probe to human DNA. The parallel assay screened for HPV-DNA by hybridisation with a cocktail of biotinylated full genomic HPV-DNA probes of the types 6,11 , $16,18,31,33,35$. All probes were obtained from Oncor Inc., Gaithensburg MD, and the dot-blot hybridisation was performed according to Katoaka et al. ${ }^{5}$

Southern-blot hybridisation: HPV-DNA positive samples (judged by the dot-blot assay) were further analysed by Southern-blot (SB) to determine which HPV genotype or genotypes were present in the samples. The $750 \mu$ l aliquots of sample preparations (see above) were then further digested with proteinase $K$ $(0.25 \mathrm{mg} / \mathrm{ml})$ in the presence of $0.5 \%$ SDS at $60^{\circ} \mathrm{C}$ for 15 minutes to facilitate DNA purification. Proteins were precipitated with salt and vigorous shaking, and removed by centrifugation. The DNA was then precipitated with $99.5 \%$ ethanol at room temperature followed by centrifugation and after two washes with $70 \%$ ethanol the DNA-pellet was dissolved in $10 \mathrm{mM}$ Tris-HCL, $1 \mathrm{mM}$ EDTA, pH 7.4. After restriction enzyme digestion with a mixture of Bam HI and PST I, the sample DNA was separated by $1 \%$ agarose gel electrophoresis together with HPV-DNA as a control and transferred by vacuum blotting (Hybaid) to positively charged nylon membranes. The membranes were hybridised with biotinylated subgenomic HPV-probes types 6, 11, 16, 18,

Table 1 Detection of HPV DNA in 88 penile condyloma-like lesions exhibiting various gross appearance (double infection in 6 cases)

\begin{tabular}{lllllll}
\hline \multirow{2}{*}{$\begin{array}{l}\text { Gross } \\
\text { morphology }\end{array}$} & \multirow{2}{*}{$\begin{array}{l}\text { No of } \\
\text { lesions }\end{array}$} & HPV DNA & \multicolumn{5}{l}{ HPV DNA positive } \\
\cline { 3 - 7 } & negative & Type 6/11 & $16 / 18$ & $31 / 33 / 35$ & Unknown \\
\hline Acuminate & 36 & 1 & 31 & 1 & 2 & 3 \\
$\begin{array}{l}\text { Papular } \\
\text { Macular }\end{array}$ & 34 & 4 & 24 & 5 & 2 & 2 \\
Total & 88 & 9 & 2 & 7 & 3 & 3 \\
\hline
\end{tabular}

$31,33,35$ under the conditions described by Katoaka et al. $^{5}$ The probes were obtained from Oncor Inc., Gaithensburg MD.

\section{Histopathology}

Fifty one patients had biopsies available for histopathological re-evaluation. Slides were examined without knowledge of the initial diagnosis or the results of hybridisation tests.

The histological criteria for diagnosis of HPV infection were the presence of koilocytosis, accanthosis, papillomatosis, mild nuclear variation in size and form and bi- or multinucleated cells. Lesions without at least minute foci of koilocytosis were recorded as doubtful or negative depending on the extent to which they fulfilled the other criteria.

Koilocytotic lesions with regular basal and parabasal layers but irregular enlarged and hyperchromatic nuclei in more superficial cells were recorded as atypical koilocytosis. Only lesions having disturbed polarity and cellular polymorphism extending into the basal layers were included in the groups of moderate and severe dysplasia.

\section{Statistical analysis}

Fischer's exact test was used for testing corelations between HPV types and macro/micromorphology.

\section{Results}

Dot blot/Southern blot: In six of 94 cases the content of DNA in the sample was insufficient for the dot blot analysis. In $79(90 \%)$ of 88 patients HPV-DNA was detected. All of the nine cases negative for HPV-DNA in the dot blot assay had histology consistent with HPV infection. In four of the dot blot positive samples Southern blot could not be performed because of insufficient material. Of $75 \mathrm{dot}$ blot positive lesions tested for HPV types $6,11,16$, 18, 31, 33 and 35 with Southern blot, 65 were positive for one type and six for two HPV types. Four dot blot positive lesions were negative for all HPV probes used in the Southern blot.

Type 6 was detected in $51(68 \%)$, type 11 in six (8\%), type 16 in eleven (15\%), type 18 in two (2\%), type 31 in five $(7 \%)$ and type 33 and 35 in one $(1 \%)$ of the dot blot positive lesions. Altogether HPV type 6 or 11 was detected in $57(76 \%)$ and HPV type $16,18,31,33$ or 35 in $20(27 \%)$ of the examined lesions. In five cases both HPV type 6 or 11 and HPV 16,18 or 31 were identified and in one case HPV 16 and 31 were found in the same lesion.

Gross appearance/HPV type (table 1). HPV types $16 / 18$ were detected significantly more often in macular lesions than in acuminate lesions $(p=0.001)$. The prevalence of HPV types 31, 33 and 35 in macular ( 3 of 18) and acuminate lesions (2 of 36 ) did not differ significantly.

Histopathology (tables 2 and 3). Of 51 biopsies evaluated, an evident koilocytosis was demonstrated in $45(88 \%)$, doubtful in three and two cases were negative. The latter were two patients with papular lesions positive for 
Table 2 Histological findings in relation to gross morphology in 51 penile condyloma-like lesions

\begin{tabular}{lllll}
\hline $\begin{array}{l}\text { Gross } \\
\text { morphology }\end{array}$ & No lesions & Koilocytosis & $\begin{array}{l}\text { Koilocytotic } \\
\text { atypia }\end{array}$ & $\begin{array}{l}\text { Dsyplasia } \\
\text { (moderate/severe) }\end{array}$ \\
\hline Acuminate & 14 & 12 & 0 & 0 \\
Papular & 21 & 18 & 6 & 4 \\
Macular & 16 & 15 & 13 & 11 \\
Total & 51 & 45 & 19 & 15 \\
\hline
\end{tabular}

Table 3 Comparison of histopathology and HPV type in 49 penile condyloma-like lesions

\begin{tabular}{lllll}
\hline HPV type & No lesions & Koilocytosis & $\begin{array}{l}\text { Koilocytotic } \\
\text { atypia }\end{array}$ & $\begin{array}{l}\text { Dysplasia } \\
\text { (moderate/severe) }\end{array}$ \\
\hline $\begin{array}{l}\text { Low-risk } \\
\quad 6 / 11\end{array}$ & 25 & 20 & & 1 \\
$\begin{array}{l}\text { High-risk } \\
\quad \text { 16/18/31/33/35 }\end{array}$ & 14 & 14 & 11 & 10 \\
$\begin{array}{l}\text { Unknown } \\
\quad \text { DB pos) }\end{array}$ & 3 & 3 & & 1 \\
Negative & 7 & 7 & 2 & 3 \\
Insufficient DNA & 2 & 2 & 0 & 0 \\
\hline
\end{tabular}

${ }^{\star}$ Includes three cases of double infection with HPV 6 or 11 .

HPV 6. In 15 lesions (29\%) dysplasia was observed, in five cases classified as moderate and in 10 as severe. Moderate or severe dysplasia was seen significantly more frequently in macular (11 of 16) than in papular lesions $(4$ of 21$)(p=0.005)$.

There was also a significant correlation $(p=$ 0.001 ) between dysplasia and the detection of a "high-risk" HPV type (table 3). However, in one lesion positive for HPV 18 and in three positive for HPV 31 there were no histological signs of dysplasia. Moderate dysplasia was recorded in one papular lesion positive for HPV type 6. Dysplasia was not found in any acuminate lesion.

\section{Discussion}

Classical acuminate condylomata are easily diagnosed clinically. Papular and especially macular condyloma-like lesions offer greater differential diagnostic problems. Histopathologically, the presence of koilocytosis is considered a pathognomonic sign of HPV infection. ${ }^{6}$ In the present study, HPV infection was confirmed in all lesions either by demonstration of koilocytosis or by positive DNA probing. About $90 \%$ of the examined lesions were positive in the HPV-DNA hybridisation test and the sensitivity for koilocytosis histologically was in the same range, $88 \%$. Of 49 lesions with results available for both histopathology and the HPV test, the diagnosis was verified by both methods in $74 \%$, by histopathology only in $14 \%$ and by a positive HPV test in $12 \%$. High-risk HPV types were detected in $8 \%$ of acuminate lesions, in $24 \%$ of papular lesions and in $56 \%$ of macular lesions. Gross et al did not find any high-risk HPV types ir 29 examined biopsy specimens from acuminate condylomata although HPV16 DNA was detected in $33 \%$ of flat condyloma-like lesions. With the in situ DNA hybridisation technique, von Krogh et al demonstrated HPV types $16 / 18$ in $6 \%$ of acuminate condylomata and in $25 \%$ of flat lesions. ${ }^{7}$ Katelaris et al, using Southern blot, found a remarkably high fre- quency of HPV $16 / 18,52 \%$ in macroscopic and $29 \%$ in subclinical lesions. ${ }^{8}$ One reason for the difference in results may be different clinical criteria for macroscopic and subclinical lesions. Thus, Katelaris et al included as macroscopic warts also flat warts not always visible without the aid of magnification. Our results confirm that the typical acuminate condylomata are mostly caused by HPV types 6 and 11, judged as "low-risk" HPV types with respect to oncogenic potential.

In as many as $15(29 \%)$ of 51 samples examined histologically, moderate or severe dysplasia was observed. As shown for HPV lesions in the female gential tract, there was a significant correlation between the histological features of dysplasia (intraepithelial neoplasia) and "high-risk" HPV types. Dysplasia was not seen in any of 14 acuminate lesions examined histologically. Some of the cases with papular lesions fulfilled the criteria for Bowenoid papulosis, a clinical entity which we find difficult to define and of doubtful clinical significance.

Subclinical HPV infection detectable as macular acetowhite lesions is a manifestation of HPV which has recently attracted attention. ${ }^{9-15}$ The acetic acid test is not specific for HPV infection and can be difficult to evaluate clinically. Most proliferating epithelium becomes swollen and white after soaking with acetic acid. Lesions such as balanitis, psoriasis and unspecific erosions could easily be misinterpreted as subclinical HPV lesions if the diagnosis is not verified by histology and/or a HPV test. In seven cases in our series, the patient had the clinical picture of balanoposthitis often with intense redness and sometimes erosion. Two patients had been treated for long periods with mild to moderate steroid cream but without effect. After soaking with acetic acid, a characteristic picture was seen, with well-circumscribed plaques and peripheral spots. Arumainayang et al have described 49 patients with balanoposthitis showing marked koilocytosis histologically suggestive of HPV infection although HPV-DNA hybridisation was not performed. ${ }^{10}$ In cases of nonspecific balanoposthitis not responding to treatment a HPV aetiology should be considered.

The association between "high-risk" HPV types and genital cancer, especially cervix cancer, is today well documented. ${ }^{16}$ Although a high frequency of these types is demonstrated in penile condyloma-like lesions, penile cancer is a rare disease. Data indicate that the "highrisk" HPV types as well as HPV types 6 and 11 are transmitted sexually ${ }^{913-15}$ and from an epidemiological point of view it is important to diagnose these lesions also in the male patient. Until simple cheap methods of HPV typing are available, biopsy specimens for light microscopy should be taken liberally from papular and macular condyloma-like lesions. Signs of dysplasia concomitant with koilocytosis indicate a "high-risk" HPV infection. In these cases, follow-up is mandatory and recent sexual partners should be examined with cytology and preferably colposcopy. In atypical cases of balanoposthitis HPV aetiology should also be considered. 
1 Syriänen K, Syriänen S. Epidemiology of human papillomavirus infections and genital neoplasia. Scand $\mathcal{F}$ Infect Dis vuppl 1990;69:7-17.

2 Gross G, Ikenberg H, Gissmann L, Hagedorn M. Papillomavirus infection of the anogenital region: Correlation between histology, clinical picture, and virus type. Proposal of a new nomenclature. $\mathcal{f}$ Inv Derm 1985; $85: 147-52$.

3 Wade TR, Kopf AW, Ackerman AB. Bowenoid papulosis of the penis. Cancer 1978;42:1890-3.

4 Schwartz R, Janniger C. Bowenoid papulosis. $f$ Am Acad Dermatol 1991;24:261-4.

5 Katoaka A, Claesson U, Hansson BG, Eriksson M, Lindh E. Human papillomavirus infection of the male diagnosed by Southern-blot and polymerase chain reaction. $7 \mathrm{Med}$ Virol 1991;33:159-64.

6 von Krogh G. Genitoanal papillomavirus infection: diagnostic and therapeutic objectives in the light of current epidemiological observations. Int $\mathfrak{f}$ STD E AIDS 1991;2:391-404.

7 von Krogh G, Syriänen S, Syriänen K. Advantage of human papillomavirus typing in the clinical evaluation of genito-
anal warts. Experience with the in situ deoxyribonucleic anal warts. Experience with the in situ deoxyribonucleic
acid hybridization technique applied on paraffin sections. acid hybridization technique applied on

8 Katelaris P, Cossart Y, Rose B, Thompson C, Sorich E, Nightingale B, Dallas P, Morris B. Human papillomavirus: the untreated male reservoir. $f$ Urol 1988; 140:300-5.
9 Barrasso R, De Brux J, Croissant O, Orth G. High prevalence of papillomavirus-associated penile intraepithelial neoplasia in sexual partners of women with cervical intraepithelial neoplasia. $N$ Engl $f$ Med 1987; 317:7916-23.

10 Arumainayagam JT, Summathipala AHT, Smallman LA, Shahmanesh M. Flat condylomata of the penis presenting as patchy balanoposthitis. Genitourin Med 1990;66:

11 Law C, Merianos A, Thompson C, Rose B, Cossart Y, Grace J. Manifestations of anogenital HPV infection in the male partners of women with anogenital warts and/or abnormal cervical smears. Int f STD \& AIDS 1991;2:188-94.

12 Sand Petersen C, Albrechtsen J, Larsen J, et al. Subclinical human papillomavirus infection in condylomata acuminata patients attending a VD clinic. Acta Derm Venereol (Stockh) 1991;71:252-5.

13 Campion MJ, McCance DJ, Mitchell HS, Jenkins D, Singer A, Oriel D. Subclinical penile human papillomavirus infection and dysplasia in consorts of women with cervical infection and dysplasia in consorts of wom

14 Schneider A, Kirchmayr R, de Villiers EM, Gissmann L Subclinical human papillomavirus infection in male sexual partners of female carriers. $\mathcal{F}$ Urol $1988 ; 140$ $1431-4$.

15 Chow VTK, Tay SK, Tham KM, Lim-Tan SK, Bernard HU. Subclinical human papillomavirus infection of the male lower genital tract: colposcopy, histology and DNA analysis. Int $₹$ STD $\mathcal{E}$ AIDS 1991;2:41-45. 